\title{
Constraining condensed-phase formation kinetics of secondary organic aerosol components from isoprene epoxydiols
}

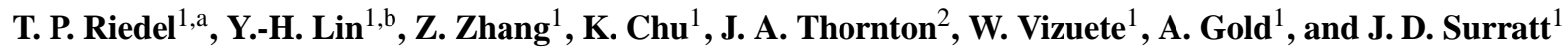 \\ ${ }^{1}$ Department of Environmental Sciences and Engineering, Gillings School of Global Public Health, \\ The University of North Carolina at Chapel Hill, Chapel Hill, North Carolina, USA \\ ${ }^{2}$ Department of Atmospheric Sciences, University of Washington, Seattle, Washington, USA \\ apresent address: US Environmental Protection Agency, National Exposure Research Laboratory, Research Triangle Park, \\ North Carolina, USA \\ b present address: Department of Chemistry, Michigan Society of Fellows, University of Michigan, \\ Ann Arbor, Michigan, USA
}

Correspondence to: J. D. Surratt (surratt@unc.edu)

Received: 29 September 2015 - Published in Atmos. Chem. Phys. Discuss.: 21 October 2015

Revised: 11 January 2016 - Accepted: 18 January 2016 - Published: 3 February 2016

\begin{abstract}
Isomeric epoxydiols from isoprene photooxidation (IEPOX) have been shown to produce substantial amounts of secondary organic aerosol (SOA) mass and are therefore considered a major isoprene-derived SOA precursor. Heterogeneous reactions of IEPOX on atmospheric aerosols form various aerosol-phase components or "tracers" that contribute to the SOA mass burden. A limited number of the reaction rate constants for these acid-catalyzed aqueous-phase tracer formation reactions have been constrained through bulk laboratory measurements. We have designed a chemical box model with multiple experimental constraints to explicitly simulate gas- and aqueous-phase reactions during chamber experiments of SOA growth from IEPOX uptake onto acidic sulfate aerosol. The model is constrained by measurements of the IEPOX reactive uptake coefficient, IEPOX and aerosol chamber wall losses, chamber-measured aerosol mass and surface area concentrations, aerosol thermodynamic model calculations, and offline filter-based measurements of SOA tracers. By requiring the model output to match the SOA growth and offline filter measurements collected during the chamber experiments, we derive estimates of the tracer formation reaction rate constants that have not yet been measured or estimated for bulk solutions.
\end{abstract}

\section{Introduction}

The gas-phase photooxidation of isoprene (2-methyl-1,3butadiene), the largest biogenic volatile organic compound (VOC) emitted worldwide (Guenther et al., 2012), yields isomeric isoprene epoxydiols (IEPOX) (Paulot et al., 2009). Subsequent acid-catalyzed multiphase chemistry of IEPOX is a significant source of secondary organic aerosol (SOA) mass (Lin et al., 2012; Surratt et al., 2010). In recent field studies, up to $50 \%$ of summertime aerosol mass loadings in the southeastern United States have been attributed to SOA resulting from IEPOX heterogeneous reactions (Budisulistiorini et al., 2013, 2015; Lin et al., 2013b). Similar IEPOXderived SOA influences are expected in areas with large isoprene emissions, such as forests primarily composed of broadleaf vegetation. As a significant SOA precursor, IEPOX has implications regarding potential climate forcing due to the scattering of incoming radiation and also impacts human health due to its large contribution to $\mathrm{PM}_{2.5}$ (particulate matter $<2.5 \mu \mathrm{m}$ in diameter) mass (Chung and Seinfeld, 2002; Dockery et al., 1993).

Gas-phase IEPOX can partition to atmospheric aerosol surface area where it can react with aerosol liquid water and aerosol-phase constituents - including sulfate, nitrate, and organics - to form a variety of lower-volatility organic compounds that can remain in the aerosol and contribute to total aerosol mass. Because their presence establishes IEPOX 
as the precursor, the particle-phase products are referred to as IEPOX-SOA "tracers" (i.e., "molecular markers"). The efficiency of gas-phase IEPOX removal by aerosol surface area is thought to be largely a function of aerosol acidity and concentration of nucleophiles that can react with accommodated IEPOX by acid-catalyzed oxirane ring opening to yield the tracer compounds (Eddingsaas et al., 2010; Gaston et al., 2014; Nguyen et al., 2014; Piletic et al., 2013; Riedel et al., 2015; Surratt et al., 2007b). Products of the reactions have been proposed to include the 2-methyltetrols (2methylthreitol and 2-methylerythritol) from addition of water, and the corresponding isomeric sulfate esters (IEPOXOS) from sulfate addition (Reactions R1 and R2) (Claeys et al., 2004; Surratt et al., 2007a).

$$
\begin{aligned}
& \operatorname{IEPOX}_{(\mathrm{aq})}+\mathrm{H}^{+}+\mathrm{H}_{2} \mathrm{O} \rightarrow 2 \text {-methyltetrols }+\mathrm{H}^{+} \\
& \operatorname{IEPOX}_{(\mathrm{aq})}+\mathrm{H}^{+}+\mathrm{SO}_{4}^{2-} \rightarrow \text { IEPOX-OS }+\mathrm{H}^{+}
\end{aligned}
$$

Products of nitrate addition, while observed less often, are also thought to be important in certain cases (Darer et al., 2011; Lin et al., 2012). Additional condensed-phase reactions are thought to form IEPOX-derived dimeric species (2-methyltetrol dimers, OS dimers), isomeric $\mathrm{C}_{5}$-alkene triols, cyclodehydration products (3-methyltetrahydrofuran3,4-diols (3-MeTHF-3,4-diols)), and higher-order oligomers which have also been identified in field and chamber studies (Lin et al., 2012, 2014, 2013b; Wang et al., 2005). In the aerosol phase, these oligomers or other high-molecularweight aerosol species may be in dynamic equilibrium with low-molecular-weight tracers (i.e., equilibrium between monomers and oligomers) (Kolesar et al., 2015). The formation of unsaturated IEPOX-derived oligomers has been linked to brown carbon formation and therefore potential radiative forcing (Lin et al., 2014). General acids, such as bisulfate, can also serve as oxirane ring-opening catalysts, though rates for such reactions tend to be significantly slower than rates for acid catalysis under the majority of aerosol conditions (Eddingsaas et al., 2010; Gaston et al., 2014).

To date, only the formation of IEPOX-derived 2methyltetrols and/or organosulfates has been investigated through direct bulk kinetic measurements (Cole-Filipiak et al., 2010), the extension of bulk kinetic measurements of surrogate epoxides (Eddingsaas et al., 2010), and computational estimates (Piletic et al., 2013). While the tetrol and IEPOXOS tracers are responsible for a sizeable fraction of IEPOXderived SOA (Lin et al., 2013a, b), the remaining tracer formation reactions have yet to be examined, and accurate estimates would benefit SOA modeling efforts (Karambelas et al., 2014; McNeill et al., 2012; Pye et al., 2013). Here we present an approach that combines chamber experiments, offline quantification of SOA tracers from filter samples using authentic standards, and modeling to estimate the formation reaction rate constants of IEPOX-derived SOA tracers whose formation rates are currently unknown. This has been done for a single seed aerosol system, acidified ammonium sulfate at low relative humidity $(\mathrm{RH})$, but the estimated rate coefficients are anticipated to be independent of the seed aerosol used.

\section{Methods}

\subsection{Chamber experiments}

Experiments were conducted under dark conditions in an indoor $10 \mathrm{~m}^{3}$ Teflon smog chamber at the University of North Carolina at Chapel Hill (UNC) (Lin et al., 2014; Riedel et al., 2015). Acidic ammonium sulfate seed aerosol was injected into the dry $(\mathrm{RH}<5 \%)$ chamber using a custom-built atomizer with an atomizing solution of $0.06 \mathrm{M}\left(\mathrm{NH}_{4}\right)_{2} \mathrm{SO}_{4}$ and $0.06 \mathrm{M} \mathrm{H}_{2} \mathrm{SO}_{4}$ until the desired total aerosol mass concentration was achieved. After seed injection, the chamber was left static for at least $30 \mathrm{~min}$ to ensure that the seed aerosol concentration was stable and uniformly mixed. IEPOX was then injected into the chamber for $2 \mathrm{~h}$ by passing $\sim 4 \mathrm{~L} \mathrm{~min}^{-1}$ of $\mathrm{N}_{2(\mathrm{~g})}$ through a glass manifold heated at $60^{\circ} \mathrm{C}$ containing $50-300 \mu \mathrm{L}$ of a $100 \mathrm{mg} \mathrm{mL}^{-1}$ ethyl acetate solution of trans- $\beta$-IEPOX (Zhang et al., 2012), the predominant IEPOX isomer (Bates et al., 2014). The majority of the SOA mass growth occurred within the first hour of the injection period; after $2 \mathrm{~h}$, significant SOA growth had ceased after the majority of IEPOX was injected and reacted.

Chamber aerosol number distributions, which were subsequently converted to total aerosol surface area and volume concentrations, were measured by a scanning electrical mobility system (SEMS v5.0, Brechtel Manufacturing Inc. - BMI) containing a differential mobility analyzer (DMA, BMI) coupled to a mixing condensation particle counter (MCPC Model 1710, BMI). Total volume concentration of seed aerosols was converted to total mass concentration assuming a density of $1.6 \mathrm{~g} \mathrm{~mL}^{-1}$, in accord with aerosol thermodynamic model outputs described in more detail below, and SOA total volume concentration was converted to total mass concentrations assuming a density of $1.25 \mathrm{~g} \mathrm{~mL}^{-1}$ (Kroll et al., 2006). The chamber RH and temperature were monitored with a commercial RH/temperature probe (OM62, Omega Engineering Inc.).

\subsection{SOA tracer quantification}

On completion of IEPOX injection, a filter sample was collected for analysis of the chamber-generated SOA. Aerosols were collected onto $46.2 \mathrm{~mm}$ Teflon filters (part no.: SF17471, Tisch Scientific) in a stainless-steel filter holder for $2 \mathrm{~h}$ at $\sim 15 \mathrm{~L} \mathrm{~min}^{-1}$ with a carbon strip denuder (Sunset Labs) upstream of the filter holder. Filters were stored in $20 \mathrm{~mL}$ scintillation vials at $-20^{\circ} \mathrm{C}$ prior to extraction and analysis. Denuder efficiency tests were performed by passing $\sim 500$ ppbv of IEPOX in $\mathrm{N}_{2(\mathrm{~g})}$ at low $\mathrm{RH}(<5 \%)$ through the denuder at $2 \mathrm{~L} \mathrm{~min}^{-1}$. Approximately $80 \%$ of IEPOX was removed from the sampling stream under these condi- 
tions, as measured by an iodide-adduct high-resolution timeof-flight chemical ionization mass spectrometer (HR-TOFCIMS, Aerodyne Research Inc.) (Lee et al., 2014). The denuder is expected to be less efficient at the higher flow velocities and shorter residence times during filter collection.

As described in previous studies (Lin et al., 2012; Surratt et al., 2010), IEPOX-derived SOA components were extracted from filters with high-purity methanol prior to analysis. Analysis was performed on a gas chromatograph coupled to a mass spectrometer equipped with an electron ionization source (GC/EI-MS, Hewlett-Packard 5890 Series II GC coupled to a Hewlett-Packard 5971A MS) and an ultra-performance liquid chromatograph/high-resolution quadrupole time-of-flight mass spectrometer equipped with electrospray ionization (UPLC/ESI-HR-QTOFMS, Agilent 6500 Series). 2-Methyltetrols, $\mathrm{C}_{5}$-alkene triols, 3-MeTHF3,4-diols, and the IEPOX-derived dimer were quantified by GC/EI-MS with prior trimethylsilylation. GC/EI-MS calibrations were performed with authentic 2-methyltetrol and 3-MeTHF-3,4-diol standards (Budisulistiorini et al., 2015; Zhang et al., 2012). In the absence of authentic standards, the triols and dimer were assumed to have the same response factor as the 2-methyltetrols (Lin et al., 2012, 2013b). Aliquots of filter extracts were reconstituted in a 50:50 $(v / v)$ methanol: water mixture from which the IEPOX-OS and IEPOX-derived dimer organosulfate (IEPOX-dimerOS) were quantified using UPLC/ESI-HR-QTOFMS operated in the negative ion mode. An authentic IEPOX-OS standard was used for calibration, and IEPOX-dimerOS was assumed to have the same response factor as the IEPOX-OS standard (Budisulistiorini et al., 2015).

\subsection{Model setup and evaluation}

Reaction kinetics of SOA generation were investigated with a zero-dimensional time-dependent chemical box model incorporating explicit aqueous-phase tracer formation. The model is initialized with the amount of trans- $\beta$-IEPOX added to the injection manifold and the measured seed aerosol total surface area and mass concentration. Estimates of the aqueous-phase molar concentrations of the inorganic seed aerosol species $\left(\left[\mathrm{H}^{+}\right],\left[\mathrm{H}_{2} \mathrm{O}\right],\left[\mathrm{HSO}_{4}^{-}\right],\left[\mathrm{SO}_{4}^{2-}\right]\right)$ and the total volume of the aqueous phase were obtained from the Extended AIM Aerosol Thermodynamics Model III (AIM, http: //www.aim.env.uea.ac.uk/aim/aim.php) (Clegg et al., 1998; Wexler and Clegg, 2002). The composition of the atomizer solution was used as the AIM inputs with a RH of $10 \%$, as AIM does not allow RH inputs $<10 \%$. As is typical with aerosol thermodynamic model calculations, the aerosol components were treated as a metastable solution, thereby suppressing the formation of solid-phase species (Hennigan et al., 2015). Given the low chamber RH and the composition of the atomizer solution, the seed aerosol was highly acidic, and this assumption is likely valid (Cziczo et al., 1997; Seinfeld and Pandis, 2006). While some gas-phase measure- ments might be used to constrain aerosol thermodynamic models like AIM, such measurements (e.g., gas-phase ammonia) were unavailable for this study. Furthermore, the actual state of aerosols at low RH is difficult to represent in such models. As a consequence, estimates presented here may be limited by the ability of so-called "reverse-mode" thermodynamic aerosol model calculations to appropriately represent the aerosols in the chamber.

A constant IEPOX-aerosol reaction probability $(\gamma)$ of 0.021 was assumed over the course of modeled experiments, which is consistent with that measured for similar seed aerosol systems (Gaston et al., 2014; Riedel et al., 2015). The resulting pseudo-first-order heterogeneous uptake rate coefficient $\left(k_{\text {het }}\right)$ of IEPOX to the aerosol phase was then calculated by Eq. (1):

$k_{\text {het }}=\gamma S_{\mathrm{a}} \omega / 4$,

where $S_{\mathrm{a}}$ is the total seed aerosol surface area concentration, and $\omega$ is the mean molecular speed of gas-phase IEPOX. This approach neglects gas-phase diffusion - the effects of which are expected to be minor for the $\gamma$ and particles sizes involved here (Gaston et al., 2014; Thornton et al., 2003). Aerosol-phase diffusion, adsorption/desorption of aerosol components, and other potential limitations that, while uncertain, have been explored in 1-D model studies for other systems are also not considered (Roldin et al., 2014; Shiraiwa et al., 2013; Wilson et al., 2012). Once IEPOX has partitioned to the particle phase $\left(\operatorname{IEPOX}_{(\mathrm{aq})}\right)$ it is allowed to react with the aerosol constituents to form the SOA tracer species. In addition to Reactions (R1) and (R2), the model incorporates acid-catalyzed reactions to form $\mathrm{C}_{5}$-alkene triols, 3-MeTHF-3,4-diols, IEPOX-dimer, and IEPOX-dimerOS Reactions (R3)-(R6) below. The model also tracks the formation of "other SOA" - defined as the difference between the chamber-measured SOA mass and the sum of the quantified tracer mass loadings - comprised of unidentified SOA products, most likely from acid-catalysis, as is the case for the other IEPOX tracers. Species comprising other SOA may be oligomers formed by acid-catalyzed coupling of tetrols or IEPOX-OS with IEPOX concomitant with reactive uptake (Lin et al., 2014). Since we are unable to differentiate the extent to which the other SOA is formed from these two, or other, pathways, the model assumes all of the other SOA is formed from reactions of IEPOX-OS with IEPOX (Reaction R7) and has a molecular weight of $334 \mathrm{~g} \mathrm{~mole}^{-1}$, the same as that of IEPOX-dimerOS.

$$
\begin{aligned}
& \text { IEPOX }_{(\mathrm{aq})}+\mathrm{H}^{+} \rightarrow \mathrm{C}_{5} \text {-alkene triols }+\mathrm{H}^{+} \\
& \operatorname{IEPOX}_{(\mathrm{aq})}+\mathrm{H}^{+} \rightarrow 3 \text {-MeTHF-3,4-diols }+\mathrm{H}^{+} \\
& \text {IEPOX }_{(\mathrm{aq})}+\mathrm{H}^{+}+2 \text {-methyltetrols } \rightarrow \text { IEPOX-dimer }+\mathrm{H}^{+} \\
& \text {IEPOX }_{(\mathrm{aq})}+\mathrm{H}^{+}+\text {IEPOX-OS } \rightarrow \text { IEPOX-dimerOS }+\mathrm{H}^{+} \\
& \text {IEPOX }_{(\mathrm{aq})}+\mathrm{H}^{+}+\text {IEPOX-OS } \rightarrow \text { other SOA }+\mathrm{H}^{+}
\end{aligned}
$$


The coupled differential equations corresponding to the production and/or loss of $\operatorname{IEPOX}_{(\mathrm{g})}$, $\operatorname{IEPOX}_{(\mathrm{aq})}, 2$ methyltetrols, IEPOX-OS, $\mathrm{C}_{5}$-alkene triols, 3-MeTHF-3,4diols, IEPOX-dimer, IEPOX-dimerOS, other $\mathrm{SOA}, \mathrm{HSO}_{4}^{-}$, and $\mathrm{SO}_{4}^{2-}$ are integrated over the entire IEPOX injection duration $(2 \mathrm{~h})$ or until the observed chamber SOA mass concentration has reached a maximum. $\left[\mathrm{H}^{+}\right]$and $\left[\mathrm{H}_{2} \mathrm{O}\right]$ are held constant over the course of a model run. Under the assumption that $\mathrm{HSO}_{4}^{-}$is converted to $\mathrm{SO}_{4}^{2-}$ as $\mathrm{SO}_{4}^{2-}$ forms IEPOX-OS, the equilibrium ratio $\left(R_{\mathrm{SO}_{4}} \equiv \mathrm{SO}_{4}^{2-} / \mathrm{HSO}_{4}^{-}\right)$is held constant. Additionally, a general first-order loss, Reaction (R8) from the formation of volatile products that do not contribute to the overall SOA mass, is applied to $\operatorname{IEPOX}_{(\mathrm{aq})}$.

$\operatorname{IEPOX}_{(\mathrm{aq})} \rightarrow$ volatile products

This reaction lowers the molar SOA yield $\left(\varphi_{\mathrm{SOA}}\right)$ below unity. First-order wall losses estimated for the chamber from a previous study are also applied to gas-phase IEPOX $\left(k_{\text {wall }}=9.4 \times 10^{-5} \mathrm{~s}^{-1}\right)$ and all aerosol-phase species $\left(k_{\text {wall-aerosol }}=1 \times 10^{-5} \mathrm{~s}^{-1}\right)$ (Riedel et al., 2015). The rate of IEPOX injection into the chamber is simulated in the model by an exponential decay of IEPOX in the injection manifold. The decay constant $(\lambda)$ was varied between $1 \times 10^{-3}$ and $2 \times 10^{-3} \mathrm{~s}^{-1}$ as a fitting parameter to better match the timescale of observed SOA growth. However, over the $2 \mathrm{~h}$ duration of the experiment, the value of the decay constant had a negligible effect on the final model-predicted SOA growth.

The complete set of differential equations used to track each of the individual species in the model is provided in Eqs. (2)-(12).

$$
\begin{aligned}
& \frac{\mathrm{d}\left[\operatorname{IEPOX}_{(\mathrm{g})}\right]}{\mathrm{d} t}=\lambda\left[\operatorname{IEPOX}_{(\text {manifold })}\right]-k_{\text {het }}\left[\operatorname{IEPOX}_{(\mathrm{g})}\right] \\
& -k_{\mathrm{wall}}\left[\operatorname{IEPOX}_{(\mathrm{g})}\right] \\
& \frac{\mathrm{d}\left[\operatorname{IEPOX}_{(\mathrm{aq})}\right]}{\mathrm{d} t}=k_{\mathrm{het}}\left[\operatorname{IEPOX}_{(\mathrm{g})}\right]-k_{\mathrm{R} 1}\left[\operatorname{IEPOX}_{(\mathrm{aq})}\right]\left[\mathrm{H}_{2} \mathrm{O}\right]\left[\mathrm{H}^{+}\right] \\
& -k_{\mathrm{R} 2}\left[\operatorname{IEPOX}_{(\mathrm{aq})}\right]\left[\mathrm{SO}_{4}^{2-}\right]\left[\mathrm{H}^{+}\right] \\
& -k_{\mathrm{R} 3}\left[\operatorname{IEPOX}_{(\mathrm{aq})}\right]\left[\mathrm{H}^{+}\right]-k_{\mathrm{R} 4}\left[\operatorname{IEPOX}_{(\mathrm{aq})}\right]\left[\mathrm{H}^{+}\right] \\
& -k_{\mathrm{R} 5}\left[\operatorname{IEPOX}_{(\mathrm{aq})}\right]\left[\mathrm{H}^{+}\right][\text {tetrol] } \\
& -k_{\mathrm{R} 6}\left[\operatorname{IEPOX}_{(\mathrm{aq})}\right]\left[\mathrm{H}^{+}\right][\mathrm{IEPOX}-\mathrm{OS}] \\
& -k_{\mathrm{R} 7}\left[\operatorname{IEPOX}_{(\mathrm{aq})}\right]\left[\mathrm{H}^{+}\right][\text {IEPOX-OS] } \\
& -k_{\mathrm{R} 8}\left[\operatorname{IEPOX}_{(\mathrm{aq})}\right]-k_{\text {wall-aerosol }}\left[\operatorname{IEPOX}_{(\mathrm{aq})}\right] \\
& \frac{\mathrm{d}[\text { tetrol }]}{\mathrm{d} t}=k_{\mathrm{R} 1}\left[\operatorname{IEPOX}_{(\mathrm{aq})}\right]\left[\mathrm{H}_{2} \mathrm{O}\right]\left[\mathrm{H}^{+}\right] \\
& -k_{\text {wall-aerosol }}[\text { tetrol] } \\
& \frac{\mathrm{d}[\text { IEPOX-OS }]}{\mathrm{d} t}=k_{\mathrm{R} 2}\left[\operatorname{IEPOX}_{(\mathrm{aq})}\right]\left[\mathrm{SO}_{4}^{2-}\right]\left[\mathrm{H}^{+}\right] \\
& -k_{\text {wall-aerosol [IEPOX-OS] }} \\
& \frac{\mathrm{d}[\text { triol }]}{\mathrm{d} t}=k_{\mathrm{R} 3}\left[\operatorname{IEPOX}_{(\mathrm{aq})}\right]\left[\mathrm{H}^{+}\right]-k_{\text {wall-aerosol }}[\text { triol }]
\end{aligned}
$$

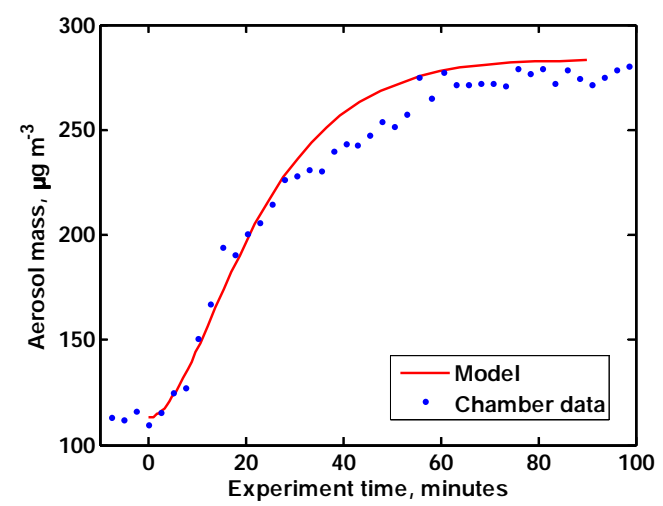

Figure 1. Aerosol mass loadings from IEPOX-SOA Exp. no. 1 and corresponding model output. IEPOX injection starts at experiment time $t=0 \mathrm{~min}$.

$$
\begin{aligned}
& \frac{\mathrm{d}[\text { diolTHF }]}{\mathrm{d} t}=k_{\mathrm{R} 4}\left[\operatorname{IEPOX}_{(\mathrm{aq})}\right]\left[\mathrm{H}^{+}\right] \\
& -k_{\text {wall-aerosol }}[\text { diolTHF] } \\
& \frac{\mathrm{d}[\text { dimer }]}{\mathrm{d} t}=k_{\mathrm{R} 5}\left[\operatorname{IEPOX}_{(\mathrm{aq})}\right]\left[\mathrm{H}^{+}\right][\text {tetrol }] \\
& -k_{\text {wall-aerosol[dimer] }} \\
& \frac{\mathrm{d}[\text { dimerOS }]}{\mathrm{d} t}=k_{\mathrm{R} 6}\left[\text { IEPOX }_{(\mathrm{aq})}\right]\left[\mathrm{H}^{+}\right][\text {IEPOX-OS }] \\
& -k_{\text {wall-aerosol }}[\text { dimerOS] } \\
& \frac{\mathrm{d}[\text { other }]}{\mathrm{d} t}=k_{\mathrm{R} 7}\left[\text { IEPOX }_{(\mathrm{aq})}\right]\left[\mathrm{H}^{+}\right][\text {IEPOX-OS }] \\
& -k_{\text {wall-aerosol }}[\text { other] } \\
& \frac{\mathrm{d}\left[\mathrm{HSO}_{4}^{-}\right]}{\mathrm{d} t}=-k_{\mathrm{R} 2}\left[\operatorname{IEPOX}_{(\mathrm{aq})}\right]\left[\mathrm{H}^{+}\right]\left[\mathrm{HSO}_{4}^{-}\right] R_{\mathrm{SO}_{4}} \\
& -k_{\text {wall-aerosol }}\left[\mathrm{HSO}_{4}^{-}\right] \\
& \frac{\mathrm{d}\left[\mathrm{SO}_{4}^{2-}\right]}{\mathrm{d} t}=k_{\mathrm{R} 2}\left[\mathrm{IEPOX}_{(\mathrm{aq})}\right]\left[\mathrm{H}^{+}\right]\left[\mathrm{HSO}_{4}^{-}\right] R_{\mathrm{SO}_{4}} \\
& -k_{\mathrm{R} 2}\left[\operatorname{IEPOX}_{(\mathrm{aq})}\right]\left[\mathrm{H}^{+}\right]\left[\mathrm{SO}_{4}^{2-}\right] \\
& -k_{\text {wall-aerosol }}\left[\mathrm{SO}_{4}^{2-}\right]
\end{aligned}
$$

Rate constants $(k)$ for Reactions (R1)-(R8) were systemically varied until model output closely matched the offline tracer measurements. Initial values were assigned to $k_{\mathrm{R} 1}-$ $k_{\mathrm{R} 8}$, and the model was run in a continuous loop, varying each rate constant to minimize the sum of the squares of the differences between the filter measurements and model output, under the constraint that all $k>0$. Functions available in MATLAB's Optimization Toolbox were used to perform the minimization. Implicitly, this approach assumes that tracer quantitations are robust, a correct representation of IEPOXderived SOA speciation and mass loading, and that the filter collection and extraction efficiency are $100 \%$. 


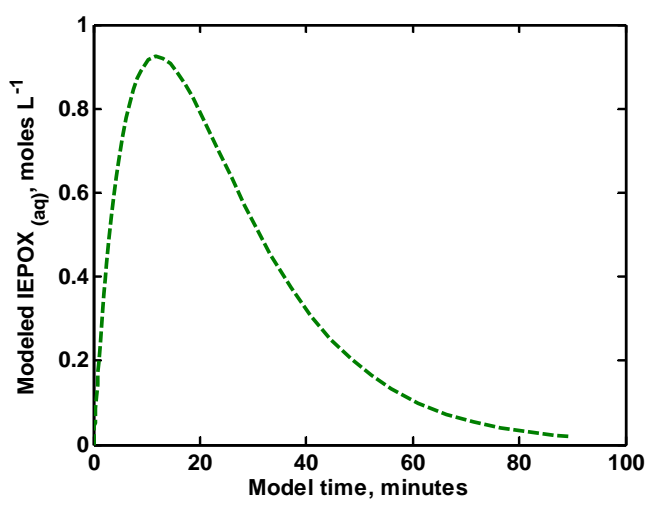

Figure 2. Model output of aqueous-phase IEPOX concentrations during Exp. no. 1 simulation.

\section{Results and discussion}

\subsection{Model output and comparison to chamber data}

Five chamber experiments were performed with the low-RH $\left(\mathrm{NH}_{4}\right)_{2} \mathrm{SO}_{4}+\mathrm{H}_{2} \mathrm{SO}_{4}$ seed aerosol system. Table 1 lists initial chamber conditions, including seed aerosol surface area and mass loading and the mass of IEPOX placed in the injection manifold. Figure 1 shows aerosol mass data and the corresponding model simulation for one experiment (Exp. no. 1). The initial seed aerosol mass loading is $113 \mu \mathrm{g} \mathrm{m}^{-3}$, and IEPOX injection is initiated at experiment time $(t)=0$. SOA mass growth is most rapid for $30 \mathrm{~min}$ post-injection and slows thereafter, reaching a maximum total aerosol mass concentration of $\sim 275 \mu \mathrm{g} \mathrm{m}^{-3}$ at $t \approx 90 \mathrm{~min}$. The timescale of SOA growth for other experiments was similar to that in Fig. 1. Figure 2 shows the model-predicted aqueousphase IEPOX concentration for Exp. no. 1. Despite the large amount of IEPOX injected into the chamber, the maximum predicted aqueous-phase IEPOX concentration reaches only 0.92 moles $^{-1}$ due to rapid formation of the SOA products. For all simulated experiments, the model reproduced the SOA growth well, both the rate and the maximum mass loading. Nevertheless, caution is necessary in interpreting the significance of this agreement since the model parameters are adjusted to maximize the agreement.

Figure 3 compares the modeled evolution of the SOA tracers in Exp. no. 1 to offline measurements of the corresponding tracers. Measured tracer mass loadings for all experiments are provided in Table 2. The tracer concentrations predicted by the model agree well with the filter measurements, differing by $<5 \%$ for all tracers.

The model also predicts significant titration of total aqueous inorganic sulfate species $\left(\left[\mathrm{SO}_{4}^{2-}\right]+\left[\mathrm{HSO}_{4}^{-}\right]\right)$over the course of each experiment due to the formation of IEPOXOS, IEPOX-dimerOS, and other SOA. Sulfate loadings were predicted to drop 36,28 , and $27 \%$ for the 30,15 , and $5 \mathrm{mg}$ IEPOX injections, respectively. Figure 4 shows the model-

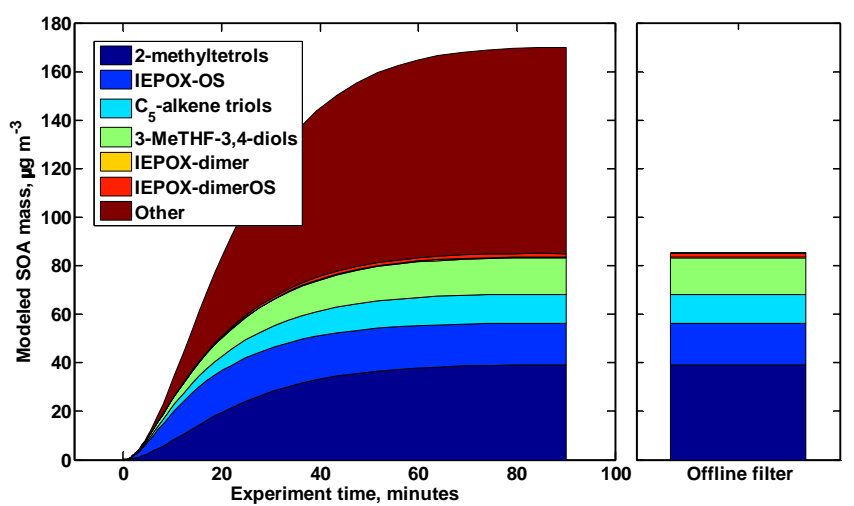

Figure 3. Model output of IEPOX-SOA tracers (left panel) and the associated filter-based tracer measurements (right panel) for Exp. no. 1. The "other SOA" is calculated as the difference between the chamber-measured aerosol mass loadings and the sum of the filter-based tracer loadings.

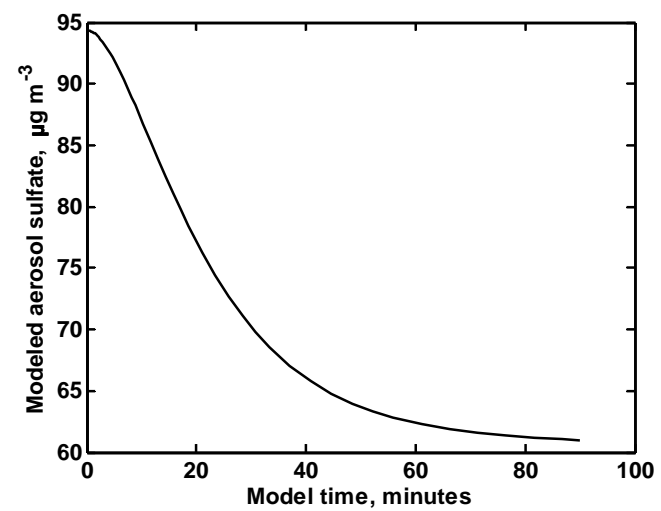

Figure 4. Model output of predicted titration of total inorganic aerosol sulfate $\left(\left[\mathrm{SO}_{4}^{2-}\right]+\left[\mathrm{HSO}_{4}^{-}\right]\right)$due to sulfated tracer formation during Exp. no. 1 simulation.

predicted sulfate titration for Exp. no. 1, in which sulfate loading drops from an initial value of $\sim 95$ to $\sim 60 \mu \mathrm{g} \mathrm{m}^{-3}$ at the conclusion of the model run. These titration levels closely match those reported in Surratt et al. (2007a) for a low- $\mathrm{NO}_{x}$ isoprene oxidation experiment with acidified ammonium sulfate seed aerosol.

\subsection{Model-predicted tracer formation kinetics}

The model-predicted tracer formation rate constants for Reactions (R1)-(R7) are given in Table 3. These are averaged over all experiments, and the listed errors correspond to 1 standard deviation $(1 \sigma)$. While the aerosols are not a priori ideal solutions, comparison of the rate constants obtained in this study to those estimated from prior studies provides useful insights. Eddingsaas et al. (2010) determined the pseudo-second-order formation constants for bulk solutions of cis-2,3-epoxybutane-1,4-diol and used 
Table 1. Summary of conditions for each chamber SOA experiment.

\begin{tabular}{rrrr}
\hline $\begin{array}{r}\text { Exp. } \\
\text { no. }\end{array}$ & $\begin{array}{r}\text { IEPOX injected } \\
\mathrm{mg}\end{array}$ & $\begin{array}{r}\text { Seed surface area } \\
\mu \mathrm{m}^{2} \mathrm{~cm}^{-3}\end{array}$ & $\begin{array}{r}\text { Seed mass } \\
\mu \mathrm{g} \mathrm{m}^{-3}\end{array}$ \\
\hline 1 & 30 & 1480 & 113 \\
2 & 30 & 1660 & 125 \\
3 & 15 & 1200 & 76 \\
4 & 5 & 800 & 59 \\
5 & 5 & 800 & 57 \\
\hline
\end{tabular}

Table 2. Tracer mass loadings for each chamber SOA experiment.

\begin{tabular}{|c|c|c|c|c|c|c|c|c|}
\hline \multirow[t]{2}{*}{ Exp. no. } & \multicolumn{8}{|c|}{ Loading $/ \mu \mathrm{g} \mathrm{m}^{-3}$} \\
\hline & Total SOA & 2-Methyltetrols & IEPOX-OS & $\mathrm{C}_{5}$-alkene triols & 3-MeTHF-3,4-diols & IEPOX-dimer & IEPOX-dimerOS & Other SOA \\
\hline 1 & 170.00 & 39.13 & 16.97 & 12.01 & 15.05 & 0.40 & 1.45 & 84.99 \\
\hline 2 & 185.00 & 41.35 & 23.69 & 12.17 & 13.67 & 0.70 & 3.01 & 90.41 \\
\hline 3 & 131.00 & 34.01 & 13.25 & 35.31 & 3.68 & 3.59 & 4.01 & 37.15 \\
\hline 4 & 60.99 & 3.72 & 27.13 & 18.42 & 0.04 & 0.27 & 10.51 & 0.90 \\
\hline 5 & 63.00 & 3.97 & 27.44 & 19.36 & 0.10 & 0.25 & 9.05 & 2.83 \\
\hline
\end{tabular}

the relationship between 2-methyl-2,3-epoxybutane and 2,3-epoxybutane reaction rate constants to estimate those for 2-methyl-2,3-epoxybutane-1,4-diol ( $\beta$-IEPOX). For 2methyltetrol formation, Pye et al. (2013) used the $\beta$-IEPOX value from Eddingsaas et al. (2010) and assumed a water concentration of $55 \mathrm{M}$ to derive a third-order rate constant with an explicit water dependence. The resulting rate constants are $9 \times 10^{-4} \mathrm{M}^{-2} \mathrm{~s}^{-1}$ for the overall formation reaction of 2-methyltetrol (Reaction $\mathrm{R} 1$ ) and $2 \times$ $10^{-4} \mathrm{M}^{-2} \mathrm{~s}^{-1}$ for the overall formation reaction of IEPOXOS (Reaction R2). A similar treatment can be applied to the pseudo-second-order hydrolysis rate constant (2methyltetrol formation) for a mixture of cis- and trans- $\beta$ IEPOX from Cole-Filipiak et al. (2010) to obtain a rate constant of $6.5 \times 10^{-4} \mathrm{M}^{-2} \mathrm{~s}^{-1}$. Purely computational estimates of $5.3 \times 10^{-2}$ and $5.2 \times 10^{-1} \mathrm{M}^{-2} \mathrm{~s}^{-1}$ for 2-methyltetrol and IEPOX-OS, respectively, are also available for comparison (Piletic et al., 2013). Apart from the computational study, these rate constants are of the same order as those predicted by the model, $3.4 \pm 3.2 \times 10^{-4} \mathrm{M}^{-2} \mathrm{~s}^{-1}$ for 2methyltetrols and $4.8 \pm 3.4 \times 10^{-4} \mathrm{M}^{-2} \mathrm{~s}^{-1}$ for IEPOX-OS, indicating that the model gives a reasonable representation of the kinetics of the multiphase process in light of the lowRH, non-ideal conditions in the highly concentrated chamber aerosols.

Epoxide ring-opening reactions by general acids (i.e., bisulfate) have not been explicitly included in the model. The contribution is expected to be negligible as the branching ratio between the bisulfate and $\mathrm{H}^{+}$-catalyzed reaction channels is likely to heavily favor the $\mathrm{H}^{+}$channel. For example, in Exp. no. 1, 98\% of the epoxide ring opening is predicted to proceed through the $\mathrm{H}^{+}$-catalyzed channel compared to that of bisulfate.
Table 3. Model-predicted formation reaction rate constants for IEPOX-SOA tracers.

\begin{tabular}{llc}
\hline SOA tracer formed & $k$ & Reaction \\
\hline 2-Methyltetrols & $3.4 \pm 3.2 \times 10^{-4} \mathrm{M}^{-2} \mathrm{~s}^{-1}$ & $(\mathrm{R} 1)$ \\
IEPOX-OS & $4.8 \pm 3.4 \times 10^{-4} \mathrm{M}^{-2} \mathrm{~s}^{-1}$ & $(\mathrm{R} 2)$ \\
$\mathrm{C}_{5}$-Alkene triols & $8.8 \pm 3.8 \times 10^{-4} \mathrm{M}^{-1} \mathrm{~s}^{-1}$ & $(\mathrm{R} 3)$ \\
3-MeTHF-3,4-diols & $2.6 \pm 3.5 \times 10^{-4} \mathrm{M}^{-1} \mathrm{~s}^{-1}$ & $(\mathrm{R} 4)$ \\
IEPOX-dimer & $1.3 \pm 0.7 \times 10^{-5} \mathrm{M}^{-2} \mathrm{~s}^{-1}$ & (R5) \\
IEPOX-dimerOS & $6.8 \pm 4.6 \times 10^{-5} \mathrm{M}^{-2} \mathrm{~s}^{-1}$ & (R6) \\
Other SOA & $5.7 \pm 6.9 \times 10^{-4} \mathrm{M}^{-2} \mathrm{~s}^{-1}$ & (R7) \\
\hline
\end{tabular}

Aerosol surface area was held constant at initial seed aerosol levels over the course of a model run, and thus $k_{\text {het }}$ is insensitive to additional surface area resulting from IEPOXderived SOA (Riedel et al., 2015). However, the presence of organics such as polyethylene glycol has been shown to lower $\gamma$ and therefore $k_{\text {het }}$ (Gaston et al., 2014), and it is unclear whether the presence of IEPOX-derived SOA components would have a similar effect. A consequence of the constant surface area is that the model does not account for any possible slowing of the uptake rate resulting from increased aerosol organic content. Measurements of $\gamma$ on mixed and pure IEPOX-SOA would be required to resolve this question.

As a sensitivity test to the choice of $334 \mathrm{~g} \mathrm{~mole}^{-1}$ for the molecular weight of the other SOA, individual model runs were also performed assuming a molecular weight of 100 and $600 \mathrm{~g} \mathrm{~mole}^{-1}$. As expected, these tests had the most pronounced effect on the rate constants extracted from simulations with the largest other SOA loadings, Exp. nos. 1 and 2 (see Table 2). For the $100 \mathrm{~g} \mathrm{~mole}^{-1}$ case, the resulting adjustment to the rate constants presented in Table 3 was at 
most a factor of 2.4 increase for IEPOX-OS and a $23 \%$ decrease, on average, across the remaining rate constants. For the $600 \mathrm{~g} \mathrm{~mole}^{-1}$ case, all of the rate constants were decreased by $25 \%$ on average. Apart from the IEPOX-OS rate constant under the $100 \mathrm{~g} \mathrm{~mole}^{-1}$ case, which was within $2 \sigma$, all of the rate constants resulting from these sensitivity tests fell within the stated $1 \sigma$ uncertainties given in Table 3 .

Given the estimates of the tracer formation rate constants, the calculated $k_{\text {het }}$, and the model output, the molar SOA yield $\left(\varphi_{\mathrm{SOA}}\right)$ can be estimated as the ratio of the sum of the tracer production rates over the $\operatorname{IEPOX}_{(\mathrm{g})}$ heterogeneous loss rate (Riedel et al., 2015). Averaged over the five experiments, $\varphi_{\mathrm{SOA}}=0.078 \pm 0.025(1 \sigma)$, with the largest $\varphi_{\mathrm{SOA}}$ being from the $5 \mathrm{mg}$ IEPOX injections and the smallest $\varphi_{\mathrm{SOA}}$ being from the $30 \mathrm{mg}$ injections. The drop in $\varphi_{\mathrm{SOA}}$ with increased IEPOX injection mass is a result of the increased amount of other SOA measured in these experiments. The higher molecular weight assumed for the oligomeric products relative to the molecular weight of the tracers requires less IEPOX to be reacted in order to match the total SOA mass loadings, thus driving down $\varphi_{\mathrm{SOA}}$. As described by Matsunaga and Ziemann (2010) and Zhang et al. (2014), wall losses of VOC and SOA material can effectively decrease calculated $\varphi_{\mathrm{SOA}}$ for chamber studies. Considering the IEPOX and aerosol wall-loss rate constants provided above, the corrections for these experiments are minor $(<2 \%$ change to $\left.\varphi_{\mathrm{SOA}}\right)$. In general, $\varphi_{\mathrm{SOA}}$ should mainly be a function of the availability of nucleophiles, provided there is ample time for uptake and tracer formation (Riedel et al., 2015). $\varphi_{\mathrm{SOA}}=$ 0.078 is similar to that predicted from an independent modeling approach which estimated the $\varphi_{\mathrm{SOA}}$ for this aerosol system at 0.1-0.12 (Riedel et al., 2015). These results indicate that the molar yield of SOA from IEPOX heterogeneous reactions is likely to be significantly $<1$ for the majority of atmospheric conditions where aerosols are likely to contain more water and be less acidic than in this study.

\subsection{Atmospheric implications}

Figure 5 shows the model output after $6 \mathrm{~h}$ processing time, using as inputs the rate constants from Table 3 and initial atmospheric conditions which might be representative of a daytime summer urban-rural mixed air mass: $50 \%$ $\mathrm{RH}, \sim 500 \mathrm{pptv}$ gas-phase IEPOX, and $250 \mu \mathrm{m}^{2} \mathrm{~cm}^{-3}$ of ammonium bisulfate aerosol surface area, corresponding to an aerosol mass loading of $\sim 10 \mu \mathrm{g} \mathrm{m}^{-3}$. The model predicts $0.37 \mu \mathrm{g} \mathrm{m}^{-3}$ of total SOA, with the bulk (77\%) being 2-methyltetrols, and minor amounts of IEPOX-OS (14\%), $\mathrm{C}_{5}$-alkene triols $(7 \%)$, and 3-MeTHF-3,4-diols $(2 \%)$. The remaining tracers - IEPOX-dimer, IEPOX-dimerOS, and other SOA - are predicted to form in small amounts $\left(<0.6 \mathrm{ng} \mathrm{m}^{-3}\right)$. At the increased RH and associated increase in aerosol liquid water, the 2-methyltetrols represent the majority of the formed tracers (see Eq. 4). With the lack of wall losses and the minor contribution of other SOA,

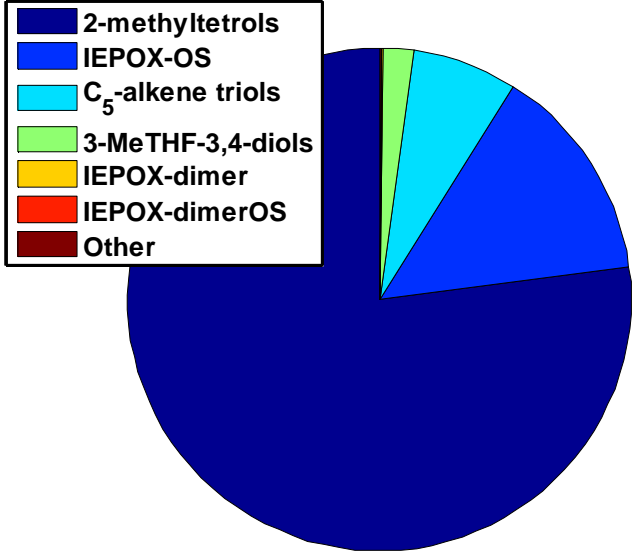

Total predicted SOA mass $=0.37 \mu \mathrm{g} \mathrm{m}^{-3}$

Figure 5. Model-predicted IEPOX-SOA tracer distribution and loadings for atmospherically relevant initial conditions.

which lowers $\varphi_{\mathrm{SOA}}$ as described above, $\varphi_{\mathrm{SOA}}$ will be larger $\left(\varphi_{\mathrm{SOA}}=0.125\right)$ for this atmospheric case compared to the chamber simulations. Additionally, this simulation predicted no appreciable titration of total aqueous inorganic sulfate, suggesting that titration is unlikely to occur in atmospheric sulfate-containing aerosols given expected IEPOX mixing ratios on the order of 1 ppbv.

Keeping in mind that we cannot hope to capture two field studies perfectly for such a general model case, the model total IEPOX tracer loading predictions are in relatively close correspondence to recent measurements in the southeastern United States. Analysis of tracers in ambient $\mathrm{PM}_{2.5}$ collected by high-volume sampling during summer 2010 in Yorkville, GA, determined that 2methyltetrols $\left(330 \mathrm{ng} \mathrm{m}^{-3}\right), \mathrm{C}_{5}$-alkene triols $\left(290 \mathrm{ng} \mathrm{m}^{-3}\right)$, and IEPOX-OS $\left(72 \mathrm{ng} \mathrm{m}^{-3}\right)$ were major constituents, with minor amounts of 3-MeTHF-3,4-diols $\left(27 \mathrm{ng} \mathrm{m}^{-3}\right)$, IEPOXdimerOS $\left(5 \mathrm{ng} \mathrm{m}^{-3}\right)$, and IEPOX-dimer $\left(0.5 \mathrm{ng} \mathrm{m}^{-3}\right)$ (Lin et al., 2012). IEPOX tracer mass loadings from analysis of high-volume $\mathrm{PM}_{2.5}$ samples collected at Look Rock, $\mathrm{TN}$, in summer 2013 as part of the Southern Oxidant and Aerosol Study (SOAS) were also dominated by IEPOXOS (169.5 $\left.\mathrm{ng} \mathrm{m}^{-3}\right)$, 2-methyltetrols $\left(163.1 \mathrm{ng} \mathrm{m}^{-3}\right)$, and $\mathrm{C}_{5}$ alkene triols $\left(144.4 \mathrm{ng} \mathrm{m}^{-3}\right)$, whereas 3-MeTHF-3,4-diols $\left(4.4 \mathrm{n} \mathrm{m}^{-3}\right)$ and IEPOX-dimerOS $\left(1.4 \mathrm{ng} \mathrm{m}^{-3}\right)$ made only minor contributions (Budisulistiorini et al., 2015).

\section{Concluding remarks}

Attempts to replicate the chamber experiments at higher $\mathrm{RH}$ $(50 \%)$ resulted in large positive deviations (1.2-2.3-fold) in total IEPOX tracer mass loadings compared to measured total aerosol mass loadings by the SEMS-MCPC. This result 
precluded the extension of these kinetic studies to include humid conditions. A possible explanation for the enhancement of filter mass loadings could be subsequent reactions at the Teflon filter surface; however, appropriate controls are required to confirm such effects. The deviation in mass loadings at higher RH indicates that artifacts may be introduced into field and chamber measurements during filter collection even when sampling through a carbon strip denuder.

Low-molecular-weight tracers with significant vapor pressures may be detected as a result of decomposition of SOA products. Such a possibility would dictate caution in adopting the kinetic estimates presented here. The sum of these formation rates would likely represent an upper limit to the formation of such SOA species under the assumption that more than one tracer could potentially be formed from the degradation of these products. However, in the absence of evidence to the contrary, there is general agreement that tracers constitute a large fraction of IEPOX-SOA, and additional investigations are required prior to the proposal that certain SOA tracers represent decomposition products.

In summary, this study is a first approach to placing kinetic constraints on the formation of species that have been quantified in laboratory and field measurements but lack directly measured experimental rate constraints. While bulk solution rate constant estimates are desirable, such measurements pose a challenge when authentic standards are unavailable or when surrogates do not adequately represent the true compounds. Additionally, it is unclear that bulk-phase kinetics can approximate aerosol-phase reactions where non-ideal conditions likely play a role. The flexible approach described here may readily be extended to other SOA production systems known to have atmospheric importance.

This study approximates tracer branching ratios for the currently proposed SOA tracers resulting from IEPOX uptake, a necessary step to predict isoprene-derived SOA production in regional models that guide policy decisions. Additional laboratory studies to identify SOA products and elucidate formation mechanisms are important to ensure that both chamber and field measurements accurately reflect atmospheric processes. Modeling developed on the basis of such experimental systems can then be extended to largescale models.

Acknowledgements. This publication was made possible in part by Environmental Protection Agency (EPA) grant no. R835404. Its contents are solely the responsibility of the grantee and do not necessarily represent the official views of the EPA. Further, the EPA does not endorse the purchase of any commercial products or services mentioned in the publication. This work is also funded in part by the National Science Foundation under CHE 1404644 and CHE 1404573 and through a grant from the Texas Commission on Environmental Quality (TCEQ), administered by The University of Texas through the Air Quality Research Program. The contents, findings, opinions, and conclusions are the work of the authors and do not necessarily represent findings, opinions, or conclusions of the TCEQ. The authors also thank Tianqu Cui and Sri Hapsari Budisulistiorini (UNC) and Felipe Lopez-Hilfiker (UW) for helpful discussions.

Edited by: M. Shiraiwa

\section{References}

Bates, K. H., Crounse, J. D., St. Clair, J. M., Bennett, N. B., Nguyen, T. B., Seinfeld, J. H., Stoltz, B. M., and Wennberg, P. O.: Gas Phase Production and Loss of Isoprene Epoxydiols, J. Phys. Chem. A, 118, 1237-1246, doi:10.1021/jp4107958, 2014.

Budisulistiorini, S. H., Canagaratna, M. R., Croteau, P. L., Marth, W. J., Baumann, K., Edgerton, E. S., Shaw, S. L., Knipping, E. M., Worsnop, D. R., Jayne, J. T., Gold, A., and Surratt, J. D.: Real-Time Continuous Characterization of Secondary Organic Aerosol Derived from Isoprene Epoxydiols in Downtown Atlanta, Georgia, Using the Aerodyne Aerosol Chemical Speciation Monitor, Environ. Sci. Technol., 47, 5686-5694, doi:10.1021/es400023n, 2013.

Budisulistiorini, S. H., Li, X., Bairai, S. T., Renfro, J., Liu, Y., Liu, Y. J., McKinney, K. A., Martin, S. T., McNeill, V. F., Pye, H. O. T., Nenes, A., Neff, M. E., Stone, E. A., Mueller, S., Knote, C., Shaw, S. L., Zhang, Z., Gold, A., and Surratt, J. D.: Examining the effects of anthropogenic emissions on isoprenederived secondary organic aerosol formation during the 2013 Southern Oxidant and Aerosol Study (SOAS) at the Look Rock, Tennessee ground site, Atmos. Chem. Phys., 15, 8871-8888, doi:10.5194/acp-15-8871-2015, 2015.

Chung, S. H. and Seinfeld, J. H.: Global distribution and climate forcing of carbonaceous aerosols, J. Geophys. Res.-Atmos., 107, AAC 14-11-AAC 14-33, doi:10.1029/2001JD001397, 2002.

Claeys, M., Graham, B., Vas, G., Wang, W., Vermeylen, R., Pashynska, V., Cafmeyer, J., Guyon, P., Andreae, M. O., Artaxo, P., and Maenhaut, W.: Formation of Secondary Organic Aerosols Through Photooxidation of Isoprene, Science, 303, 1173-1176, doi:10.1126/science.1092805, 2004.

Clegg, S. L., Brimblecombe, P., and Wexler, A. S.: Thermodynamic Model of the System $\mathrm{H}^{+}-\mathrm{NH}_{4}^{+}-\mathrm{Na}^{+}-\mathrm{SO}_{4}^{2-}-\mathrm{NO}_{3}^{-}$$\mathrm{Cl}^{-}-\mathrm{H}_{2} \mathrm{O}$ at $298.15 \mathrm{~K}$, J. Phys. Chem. A, 102, 2155-2171, doi:10.1021/jp973043j, 1998.

Cole-Filipiak, N. C., O'Connor, A. E., and Elrod, M. J.: Kinetics of the Hydrolysis of Atmospherically Relevant IsopreneDerived Hydroxy Epoxides, Environ. Sci. Technol., 44, 67186723, doi:10.1021/es1019228, 2010.

Cziczo, D. J., Nowak, J. B., Hu, J. H., and Abbatt, J. P. D.: Infrared spectroscopy of model tropospheric aerosols as a function of relative humidity: Observation of deliquescence and crystallization, J. Geophys. Res.-Atmos., 102, 18843-18850, doi:10.1029/97JD01361, 1997.

Darer, A. I., Cole-Filipiak, N. C., O'Connor, A. E., and Elrod, M. J.: Formation and Stability of Atmospherically Relevant IsopreneDerived Organosulfates and Organonitrates, Environ. Sci. Technol., 45, 1895-1902, doi:10.1021/es103797z, 2011.

Dockery, D. W., Pope, C. A., Xu, X., Spengler, J. D., Ware, J. H., Fay, M. E., Ferris, B. G., and Speizer, F. E.: An Association between Air Pollution and Mortality in Six U.S. Cities, New Engl. 
J. Med., 329, 1753-1759, doi:10.1056/NEJM199312093292401, 1993.

Eddingsaas, N. C., VanderVelde, D. G., and Wennberg, P. O.: Kinetics and Products of the Acid-Catalyzed Ring-Opening of Atmospherically Relevant Butyl Epoxy Alcohols, J. Phys. Chem. A, 114, 8106-8113, doi:10.1021/jp103907c, 2010.

Gaston, C. J., Riedel, T. P., Zhang, Z., Gold, A., Surratt, J. D., and Thornton, J. A.: Reactive Uptake of an Isoprene-Derived Epoxydiol to Submicron Aerosol Particles, Environ. Sci. Technol., 48, 11178-11186, doi:10.1021/es5034266, 2014.

Guenther, A. B., Jiang, X., Heald, C. L., Sakulyanontvittaya, T., Duhl, T., Emmons, L. K., and Wang, X.: The Model of Emissions of Gases and Aerosols from Nature version 2.1 (MEGAN2.1): an extended and updated framework for modeling biogenic emissions, Geosci. Model Dev., 5, 1471-1492, doi:10.5194/gmd-51471-2012, 2012.

Hennigan, C. J., Izumi, J., Sullivan, A. P., Weber, R. J., and Nenes, A.: A critical evaluation of proxy methods used to estimate the acidity of atmospheric particles, Atmos. Chem. Phys., 15, 27752790, doi:10.5194/acp-15-2775-2015, 2015.

Karambelas, A., Pye, H. O. T., Budisulistiorini, S. H., Surratt, J. D., and Pinder, R. W.: Contribution of Isoprene Epoxydiol to Urban Organic Aerosol: Evidence from Modeling and Measurements, Environ. Sci. Technol. Lett., 1, 278-283, doi:10.1021/ez5001353, 2014.

Kolesar, K. R., Li, Z., Wilson, K. R., and Cappa, C. D.: Heating-induced evaporation of nine different secondary organic aerosol types, Environ. Sci. Technol., 49, 12242-12252, doi:10.1021/acs.est.5b03038, 2015.

Kroll, J. H., Ng, N. L., Murphy, S. M., Flagan, R. C., and Seinfeld, J. H.: Secondary Organic Aerosol Formation from Isoprene Photooxidation, Environ. Sci. Technol., 40, 1869-1877, doi:10.1021/es0524301, 2006.

Lee, B. H., Lopez-Hilfiker, F. D., Mohr, C., Kurtén, T., Worsnop, D. R., and Thornton, J. A.: An Iodide-Adduct High-Resolution Time-of-Flight Chemical-Ionization Mass Spectrometer: Application to Atmospheric Inorganic and Organic Compounds, Environ. Sci. Technol., 48, 6309-6317, doi:10.1021/es500362a, 2014.

Lin, Y.-H., Zhang, Z., Docherty, K. S., Zhang, H., Budisulistiorini, S. H., Rubitschun, C. L., Shaw, S. L., Knipping, E. M., Edgerton, E. S., Kleindienst, T. E., Gold, A., and Surratt, J. D.: Isoprene Epoxydiols as Precursors to Secondary Organic Aerosol Formation: Acid-Catalyzed Reactive Uptake Studies with Authentic Compounds, Environ. Sci. Technol., 46, 250258, doi:10.1021/es202554c, 2012.

Lin, Y.-H., Zhang, H., Pye, H. O. T., Zhang, Z., Marth, W. J., Park, S., Arashiro, M., Cui, T., Budisulistiorini, S. H., Sexton, K. G., Vizuete, W., Xie, Y., Luecken, D. J., Piletic, I. R., Edney, E. O., Bartolotti, L. J., Gold, A., and Surratt, J. D.: Epoxide as a precursor to secondary organic aerosol formation from isoprene photooxidation in the presence of nitrogen oxides, P. Natl. Acad. Sci., 110, 6718-6723, doi:10.1073/pnas.1221150110, 2013a.

Lin, Y.-H., Knipping, E. M., Edgerton, E. S., Shaw, S. L., and Surratt, J. D.: Investigating the influences of $\mathrm{SO}_{2}$ and $\mathrm{NH}_{3}$ levels on isoprene-derived secondary organic aerosol formation using conditional sampling approaches, Atmos. Chem. Phys., 13, 84578470, doi:10.5194/acp-13-8457-2013, 2013b.
Lin, Y.-H., Budisulistiorini, S. H., Chu, K., Siejack, R. A., Zhang, H., Riva, M., Zhang, Z., Gold, A., Kautzman, K. E., and Surratt, J. D.: Light-Absorbing Oligomer Formation in Secondary Organic Aerosol from Reactive Uptake of Isoprene Epoxydiols, Environ. Sci. Technol., 48, 12012-12021, doi:10.1021/es503142b, 2014.

Matsunaga, A. and Ziemann, P. J.: Gas-Wall Partitioning of Organic Compounds in a Teflon Film Chamber and Potential Effects on Reaction Product and Aerosol Yield Measurements, Aerosol Sci. Technol., 44, 881-892, doi:10.1080/02786826.2010.501044, 2010.

McNeill, V. F., Woo, J. L., Kim, D. D., Schwier, A. N., Wannell, N. J., Sumner, A. J., and Barakat, J. M.: Aqueous-Phase Secondary Organic Aerosol and Organosulfate Formation in Atmospheric Aerosols: A Modeling Study, Environ. Sci. Technol., 46, 80758081, doi:10.1021/es3002986, 2012.

Nguyen, T. B., Coggon, M. M., Bates, K. H., Zhang, X., Schwantes, R. H., Schilling, K. A., Loza, C. L., Flagan, R. C., Wennberg, P. O., and Seinfeld, J. H.: Organic aerosol formation from the reactive uptake of isoprene epoxydiols (IEPOX) onto nonacidified inorganic seeds, Atmos. Chem. Phys., 14, 3497-3510, doi:10.5194/acp-14-3497-2014, 2014.

Paulot, F., Crounse, J. D., Kjaergaard, H. G., Kürten, A., St. Clair, J. M., Seinfeld, J. H., and Wennberg, P. O.: Unexpected Epoxide Formation in the Gas-Phase Photooxidation of Isoprene, Science, 325, 730-733, doi:10.1126/science.1172910, 2009.

Piletic, I. R., Edney, E. O., and Bartolotti, L. J.: A computational study of acid catalyzed aerosol reactions of atmospherically relevant epoxides, Phys. Chem. Chem. Phys., 15, 18065-18076, doi:10.1039/C3CP52851K, 2013.

Pye, H. O. T., Pinder, R. W., Piletic, I. R., Xie, Y., Capps, S. L., Lin, Y.-H., Surratt, J. D., Zhang, Z., Gold, A., Luecken, D. J., Hutzell, W. T., Jaoui, M., Offenberg, J. H., Kleindienst, T. E., Lewandowski, M., and Edney, E. O.: Epoxide Pathways Improve Model Predictions of Isoprene Markers and Reveal Key Role of Acidity in Aerosol Formation, Environ. Sci. Technol., 47, 11056-11064, doi:10.1021/es402106h, 2013.

Riedel, T. P., Lin, Y.-H., Budisulistiorini, S. H., Gaston, C. J., Thornton, J. A., Zhang, Z., Vizuete, W., Gold, A., and Surratt, J. D.: Heterogeneous Reactions of Isoprene-Derived Epoxides: Reaction Probabilities and Molar Secondary Organic Aerosol Yield Estimates, Environ. Sci. Technol. Lett., 2, 38-42, doi:10.1021/ez500406f, 2015.

Roldin, P., Eriksson, A. C., Nordin, E. Z., Hermansson, E., Mogensen, D., Rusanen, A., Boy, M., Swietlicki, E., Svenningsson, B., Zelenyuk, A., and Pagels, J.: Modelling non-equilibrium secondary organic aerosol formation and evaporation with the aerosol dynamics, gas- and particle-phase chemistry kinetic multilayer model ADCHAM, Atmos. Chem. Phys., 14, 7953-7993, doi:10.5194/acp-14-7953-2014, 2014.

Seinfeld, J. H. and Pandis, S. N.: Atmospheric Chemistry and Physics: From Air Pollution to Climate Change, 2nd Edn., Wiley-Interscience, Hoboken, New Jersey, USA, 2006.

Shiraiwa, M., Zuend, A., Bertram, A. K., and Seinfeld, J. H.: Gasparticle partitioning of atmospheric aerosols: interplay of physical state, non-ideal mixing and morphology, Phys. Chem. Chem. Phys., 15, 11441-11453, doi:10.1039/C3CP51595H, 2013.

Surratt, J. D., Kroll, J. H., Kleindienst, T. E., Edney, E. O., Claeys, M., Sorooshian, A., Ng, N. L., Offenberg, J. H., Lewandowski, 
M., Jaoui, M., Flagan, R. C., and Seinfeld, J. H.: Evidence for Organosulfates in Secondary Organic Aerosol, Environ. Sci. Technol., 41, 517-527, doi:10.1021/es062081q, 2007a.

Surratt, J. D., Lewandowski, M., Offenberg, J. H., Jaoui, M., Kleindienst, T. E., Edney, E. O., and Seinfeld, J. H.: Effect of Acidity on Secondary Organic Aerosol Formation from Isoprene, Environ. Sci. Technol., 41, 5363-5369, doi:10.1021/es0704176, 2007b.

Surratt, J. D., Chan, A. W. H., Eddingsaas, N. C., Chan, M., Loza, C. L., Kwan, A. J., Hersey, S. P., Flagan, R. C., Wennberg, P. O., and Seinfeld, J. H.: Reactive intermediates revealed in secondary organic aerosol formation from isoprene, P. Natl. Acad. Sci., 107, 6640-6645, doi:10.1073/pnas.0911114107, 2010.

Thornton, J. A., Braban, C. F., and Abbatt, J. P. D.: $\mathrm{N}_{2} \mathrm{O}_{5}$ hydrolysis on sub-micron organic aerosols: the effect of relative humidity, particle phase, and particle size, Phys. Chem. Chem. Phys., 5, 4593-4603, doi:10.1039/b307498f, 2003.

Wang, W., Kourtchev, I., Graham, B., Cafmeyer, J., Maenhaut, W., and Claeys, M.: Characterization of oxygenated derivatives of isoprene related to 2-methyltetrols in Amazonian aerosols using trimethylsilylation and gas chromatography/ion trap mass spectrometry, Rapid Commun. Mass Sp., 19, 13431351, doi:10.1002/rcm.1940, 2005.
Wexler, A. S., and Clegg, S. L.: Atmospheric aerosol models for systems including the ions $\mathrm{H}+, \mathrm{NH} 4+, \mathrm{Na}+, \mathrm{SO}_{4}{ }^{2-}, \mathrm{NO}_{3-}$, Cl-, Br-, and $\mathrm{H}_{2} \mathrm{O}$, J. Geophys. Res.-Atmos., 107, ACH 14-11ACH 14-14, doi:10.1029/2001JD000451, 2002.

Wilson, K. R., Smith, J. D., Kessler, S. H., and Kroll, J. H.: The statistical evolution of multiple generations of oxidation products in the photochemical aging of chemically reduced organic aerosol, Phys. Chem. Chem. Phys., 14, 1468-1479, doi:10.1039/C1CP22716E, 2012.

Zhang, X., Cappa, C. D., Jathar, S. H., McVay, R. C., Ensberg, J. J., Kleeman, M. J., and Seinfeld, J. H.: Influence of vapor wall loss in laboratory chambers on yields of secondary organic aerosol, P. Natl. Acad. Sci., 111, 5802-5807, doi:10.1073/pnas.1404727111, 2014.

Zhang, Z., Lin, Y.-H., Zhang, H., Surratt, J. D., Ball, L. M., and Gold, A.: Technical Note: Synthesis of isoprene atmospheric oxidation products: isomeric epoxydiols and the rearrangement products cis- and trans-3-methyl-3,4-dihydroxytetrahydrofuran, Atmos. Chem. Phys., 12, 8529-8535, doi:10.5194/acp-12-85292012, 2012. 